Www.jmscr.igmpublication.org

Impact Factor (SJIF): 6.379

Index Copernicus Value: 79.54

ISSN (e)-2347-176x ISSN (p) 2455-0450

crossrefDOI: https://dx.doi.org/10.18535/jmscr/v6i10.23

Journal Of Medical Science And Clinical Research

IGM Publication

An Official Publication of IGM Publication

\title{
Pulmonary Function Test in Healthy Schoolchildren of 7 to 15 years age in North Kerala
}

\section{Authors \\ Dr Muhammad Shafeek. K. ${ }^{1}$, Dr Shinil V, Dr Jerin Varghese ${ }^{3}$ \\ Dr Manoj DK ${ }^{4}$, Dr Rajani.M ${ }^{5}$}

${ }^{1}$ Assistant Professor, Department of Respiratory Medicine, Pariyaram Medical College, Kannur, Kerala.

${ }^{2,3}$ Junior Resident, Department of Respiratory Medicine, Pariyaram Medical College, Kannur, Kerala

${ }^{4}$ Professor \& HOD, Department of Respiratory Medicine, Pariyaram Medical College, Kannur, Kerala

${ }^{5}$ Professor, Department of Respiratory Medicine, Pariyaram Medical College, Kannur, Kerala, India

\begin{abstract}
Background: Among the various investigation modalities available, pulmonary function test (PFT) is an invaluable tool for the assessment of lung function. PFT values are influenced by race age, sex, height, weight as well as environmental, genetic, socio-ecnomocal and technical parameters.
\end{abstract}

Objective: To determine pulmonary functions in the age group 7-15 years and to find its correlation with regards to age, sex, height, weight and body mass index.

Materials and Methods: This study was conducted among normal healthy school children of kannur aged 7 to 15 years. With preformed questionnaire children were interviewed, children with previous history of asthma and other chronic lung diseases were excluded, detailed general physical and systemic examination was done. Height, weight, body mass index were measured. All included children were tested in a sitting position with the head straight after taking written consent from parents. Spirometry was done using Micromedical Gold standard fully computerized portable auto spirometer (Superspiro Cat No. SU 6000). Statistical analysis of the data was done with SPSSv24.

Results: There were 166 children 111 boys and55 girls. Minimum FVC WAS 1.20L and maximum FVC was 3.80lMinimum FEV1was1.07 and maximum FEV1 was3.02l. FVC, FEV 1 and PEFR were found to be statistically significant in the study groups. For FVC and FEV 1, highest correlation was found with height and weight in both boys and girls. PEFR showed weak correlation with weight in boys

Conclusion: Variables such as FVC, FEV 1 show good positive correlation with height, age and body mass index in both sexes. There is a need to have regional values for the prediction of normal spirometric parameters in a country like India with considerable diversity.

Keywords: Pulmonary Function Test, Forced Vital Capacity, Peak Expiratory Flow Rate (PEFR).

\section{Introduction}

Pulmonary function test (PFT) is an invaluable tool for the assessment of lung function. PFT for lungs can be comparable to the ECG for heart ${ }^{[1]}$. Pulmonary function test (PFTs) are considered as an essential component for evaluation of lung functions, to identify the underlying cause of respiratory symptoms in children and adolescents $\&$ monitor the status of those with chronic lung diseases.PFT values are influenced by race age, sex, height, weight, environmental, genetic, socioeconomical and technical parameters. Predictive 
normal values are essential for meaningful clinical interpretation of these tests. Studies carried out in children had projected the equations for predicting different lung functions using height, age and weight as independent variables in India ${ }^{[2-5]}$ and in other countries ${ }^{[6,7]}$. From these studies, it is obvious that there are differences in spirometric parameters between Indian and western world as well as regional differences. There are only a few studies that have established reference standards for pulmonary function of Indian children. $2,8,9,10$ However, more than 120 reference standards are published for pulmonary function in white children $^{11,12,13}$. The prevalence of childhood pulmonary diseases especially bronchial asthma is increasing worldwide and this necessitates the need for establishing regression equations for predicting pulmonary functions in children. Reference standards for pulmonary function that are reported for Indian children are mainly from northern and western parts of the country ${ }^{2,8,9,10}$ and there is a paucity of data on pulmonary function in normal South Indian children. Pulmonary function is known to vary with age, sex, height, weight, race and geographic locations ${ }^{15,16}$. India, being a subcontinent, changes in pulmonary functions can occur between children of South Indian origin and children of other regions ${ }^{11,12,13}$. So, the present study was conducted with a purpose to obtain reference values for forced vital capacity (FVC), forced expiratory volume in one second $\left(\mathrm{FEV}_{1}\right)$, forced expiratory volume ratio in one second $\left(\mathrm{FEV}_{1} \%\right)$ and peak expiratory flow rate (PEFR) among children aged 7-15 years in NORTH KERALA.

\section{Objectives}

1. To study and evaluate the pulmonary functions in healthy school children of 7 to 15 years age in north Kerala.

2. To find its correlation with regards to age, sex, height, and weight and body mass index.

\section{Methodology}

This cross-sectional study was conducted in the Department of Respiratory medicine, Pariyaram medical college, Kannur, Kerala. The study was conducted among normal healthy school children of 7-15 years in KANNUR. Children with history of any febrile illness in last 2 weeks, upper respiratory tract infections (URTI) like symptoms in past 2 weeks, acute or chronic respiratory diseases, any major systemic disease like cardiac or renal problems, clinically significant anemia, $\mathrm{h} / \mathrm{o}$ any drug intake which can affect PFT, h/o any allergy, children with bone deformity of chest or spine and any muscular weakness, family history of atopy, asthma or other chronic lung diseases ,those who are unable to perform the Spirometry and those who are not willing to participate in the study were excluded from the study. The prior permission of school authorities was taken and written consent from the parents of the students involved in the study obtained. The purpose and objective of the study was explained to school authorities and parents. A detailed proforma was filled by asking parents of children, and a thorough clinical examination on each child was done to rule out any significant problems fitting the exclusion criteria. Both height and weight will be recorded. Spirometry was done using Micromedical Gold standard fully computerized portable auto spirometer (Superspiro Cat No. SU 6000). All included children was tested in a sitting position with the head straight. Before testing, the procedure was explained and demonstrated to each child. Each child was told to take a deep breath and then blow into the mouth piece as hard and fast as he/she could. At least three trials were given and best of the three was chosen for analysis, based on standardization of spirometry study based on ATS/ERS task force series ${ }^{[17]}$ and various other studies. ${ }^{[2-5,7,18]}$ The same spirometer was used throughout the study and the tests was performed by the same technician. The main spirometric parameters were measured and displayed and all data with flow-volume and volume-time curves were printed out by built-in 
thermal printer. The device uses a turbine sensor and a mouth piece required to connect a subject to the spirometer. A new disposable mouth piece was used every time in a new candidate. PEFR was measured by Wright's peak flow meter.

\section{Analysis}

Data were analysed with Spssv24.Data were described as mean+/-SD. Student $t$ test and chisquare test were used for analysing within the group. Multiple linear regression analysis also used.

Ethical clearance: The study was approved by institutional ethical and research committee.

\section{Results}

Total 166 participants, 111 boys and 55 girls. In the study group 19 (11.44\%) students gave history of passive smoking and $15(9.05 \%)$ gave history of biomass fuel exposure

Table-1 Anthropometric and lung function variables of study group as per mean \pm SD

\begin{tabular}{|l|c|c|c|c|}
\hline $\begin{array}{l}\text { CHARECTERISTI } \\
\text { CS }\end{array}$ & $\begin{array}{c}\text { MINIMU } \\
\text { M }\end{array}$ & $\begin{array}{c}\text { MAXIM } \\
\text { UM }\end{array}$ & MEAN & $\begin{array}{c}\text { STD } \\
\text { DEVIATIO } \\
\text { N }\end{array}$ \\
\hline AGE (YRS) & 7.00 & 15.00 & 12.43 & 1.24 \\
\hline HEIGHT (CM) & 123.00 & 168.00 & 148.69 & 9.18 \\
\hline WEIGHT (KG) & 18.00 & 68.00 & 39.57 & 8.26 \\
\hline BMI & 10.91 & 25.00 & 17.78 & 2.94 \\
\hline FVC(L) & 1.20 & 3.80 & 2.26 & 0.41 \\
\hline FEV1(L) & 1.07 & 3.02 & 1.98 & 0.36 \\
\hline PEFR & 198.30 & 753.00 & 299.93 & 71.69 \\
\hline
\end{tabular}

Table 2 Sex wise correlation

\begin{tabular}{|c|c|c|c|c|c|}
\hline & SEX & $\mathrm{N}$ & Mean & $\begin{array}{c}\text { Std. } \\
\text { Deviation }\end{array}$ & $\begin{array}{c}\mathrm{p} \\
\text { value* }\end{array}$ \\
\hline \multirow[t]{2}{*}{ AGE } & Female & 55 & 12.45 & 1.00 & 0.845 \\
\hline & Male & 111 & 12.41 & 1.34 & \\
\hline \multirow[t]{2}{*}{ HEIGHT } & Female & 55 & 147.64 & 9.05 & 0.298 \\
\hline & Male & 111 & 149.22 & 9.24 & \\
\hline \multirow[t]{2}{*}{ WEIGHT } & Female & 55 & 38.53 & 6.82 & \multirow[t]{2}{*}{0.255} \\
\hline & Male & 111 & 40.08 & 8.87 & \\
\hline \multirow[t]{2}{*}{ BMI } & Female & 55 & 17.63 & 2.57 & \multirow[t]{2}{*}{0.648} \\
\hline & Male & 111 & 17.85 & 3.12 & \\
\hline \multirow[t]{2}{*}{ FVC(L) } & Female & 55 & 2.17 & 0.32 & \multirow[t]{2}{*}{0.063} \\
\hline & Male & 111 & 2.30 & 0.45 & \\
\hline \multirow[t]{2}{*}{ FEV1(L) } & Female & 55 & 1.91 & 0.33 & \multirow[t]{2}{*}{0.069} \\
\hline & Male & 111 & 2.01 & 0.37 & \\
\hline \multirow[t]{2}{*}{ FEV1/FVC(\% } & Female & 55 & 87.96 & 5.07 & \multirow[t]{2}{*}{0.501} \\
\hline & Male & 111 & 87.05 & 9.25 & \\
\hline \multirow[t]{2}{*}{$\mathrm{PEF}(\mathrm{L} / \mathrm{mi})$} & Female & 55 & 269.03 & 52.12 & \multirow[t]{2}{*}{$<0.001$} \\
\hline & Male & 111 & 315.25 & 75.24 & \\
\hline
\end{tabular}

*Using Student's t test for independent means

FVC, FEV 1 and PEFR were found to be statistically significant in the study groups. For FVC and FEV 1, highest correlation was found with height and weight in both boys and girls.
PEFR showed weak correlation with weight in boys.

Correlation between various Anthropometric and Lung Function Variables in Study Group

Table-3 Correlation between various Anthropometric and FVC

\begin{tabular}{|l|c|c|}
\hline FVC & Correlation Coefficient & P Value \\
\hline Age & 0.617 & $<0.001$ \\
\hline Height & 0.891 & $<0.001$ \\
\hline Weight & 0.717 & $<0.001$ \\
\hline BMI & 0.233 & $<0.002$ \\
\hline
\end{tabular}

Table 4 Correlation between various anthropometric and FEV1

\begin{tabular}{|l|c|c|}
\hline FEV1(L) & Correlation Coefficient & P Value \\
\hline Age & 0.553 & $<0.001$ \\
\hline Height & 0.839 & $<0.001$ \\
\hline Weight & 0.738 & $<0.001$ \\
\hline BMI & 0.31 & $<0.001$ \\
\hline
\end{tabular}

Table-5 Correlation between various anthropometric FEV1/FVC

\begin{tabular}{|l|c|c|}
\hline FEV1/FVC(\%) & Correlation Coefficient & P Value \\
\hline Age & 0.041 & 0.596 \\
\hline Height & 0.058 & 0.457 \\
\hline Weight & 0.055 & 0.478 \\
\hline BMI & 0.033 & 0.674 \\
\hline
\end{tabular}

Table-6 Correlation between various anthropometric and PEFR

\begin{tabular}{|l|c|c|}
\hline PEFR & Correlation Coefficient & P Value \\
\hline Age & 0.08 & 0.308 \\
\hline Height & 0.163 & 0.036 \\
\hline Weight & 0.27 & $<0.001$ \\
\hline BMI & 0.206 & 0.008 \\
\hline
\end{tabular}

\section{Discussion}

In India, several studies were carried out on school children to predict the lung function using anthropometric variables. The present study has shown significant correlation for FVC with age, weight and height ( $p$ value $<0.001$ ). Similarly, for $\mathrm{FEV}_{1}$ significant correlation was found with age, weight and height ( $\mathrm{p}$ value $<0.001$ ) which was also reported by various authors. ${ }^{[9,19,20]}$ Shamssain et $a l,{ }^{[21]}$ in their study in Libyan children showed that FVC $(\mathrm{r}=0.442, P<0.001)$ and $\mathrm{FEV}_{1}(\mathrm{r}=0.479, P<0.001)$ were significantly less in girls than boys. Vijayan et al, ${ }^{[22]}$ in a study on south Indian children, showed that correlations of FVC and $\mathrm{FEV}_{1}$ were highest with height followed by weight and age. Height influences the prediction equations in males to a greater extent 
whereas age and weight had greater influences in girls. Wang et al, ${ }^{[23]}$ concluded that for the same height boys, have greater lung function values than girls. Similarly for PEF significant correlation was found only with weight. All the pulmonary variables were slightly higher side in males but only PEF was at a significant higher side ( $\mathrm{p}$ value <0.001). A significant positive correlation was observed between FVC, FEV1, PEFR and all the anthropometric indices. Table 7 shows a comparative study of various variables in boys and girls with other studies.

Table 7 Comparison of FVC, FEV1 and PEFR among boys and girls with other studies

\begin{tabular}{|c|c|c|c|c|c|c|}
\hline Author & No. of cases & PEFR & FVC & $\mathbf{F E V}_{1}$ & & \\
\hline \multicolumn{5}{|l|}{ For boys } & & \\
\hline $\begin{array}{l}\text { Tahera H. doctor et } \mathrm{al}^{26} \text { (south } \\
\text { Gujarat region, India) }\end{array}$ & 408 & $4.74 \pm 0.96$ & $2.01 \pm 0.46$ & $1.76 \pm 0.38$ & & \\
\hline Sharma PP et al (Delhi) & 222 & $\begin{array}{l}4.21 \pm 0.76 \\
(0.000)\end{array}$ & $\begin{array}{l}2.13 \pm 0.5 \\
(0.0019)\end{array}$ & $\begin{array}{l}2.05 \pm 0.41 \\
(0.000)\end{array}$ & & \\
\hline $\begin{array}{l}\text { Mallik SK et al (North } \\
\text { India) }\end{array}$ & 441 & - & $2.1 \pm 0.7(0.023)$ & $\begin{array}{c}1.9 \pm 0.6 \\
(0.00048)\end{array}$ & & \\
\hline Harikumaran NR (South India) & 109 & & $\begin{array}{c}1.77 \pm 0.21 \\
(0.0001)\end{array}$ & $\begin{array}{c}1.59 \pm 0.19 \\
(0.0001)\end{array}$ & & \\
\hline Present study & 111 & $3.1525 \pm 0.75$ & $2.30 \pm 0.45$ & $2.01 \pm 0.37$ & & \\
\hline \multicolumn{5}{|l|}{ For girls } & & \\
\hline Sharma PP et al (Delhi) & 188 & $\begin{array}{l}4.01 \pm 0.88 \\
(0.00067)\end{array}$ & $\begin{array}{c}1.82 \pm 0.41 \\
(0.023)\end{array}$ & $\begin{array}{l}1.73 \pm 0.43 \\
(0.296)\end{array}$ & & \\
\hline $\begin{array}{l}\text { Mallik SK et al (North } \\
\text { India) }\end{array}$ & 322 & - & $1.9 \pm 0.4(0.765)$ & $1.7 \pm 0.8(0.829)$ & & \\
\hline $\begin{array}{l}\text { Tahera H. doctor et al(south } \\
\text { Gujarat region, India) }\end{array}$ & 247 & \begin{tabular}{r|}
$4.47 \pm 1.1$ \\
$4.47 \pm 1.1$
\end{tabular} & $\begin{array}{rr}15 & 1.914 .49 \pm 1.151 . \\
1.9\end{array}$ & $\left\{\begin{array}{l}910 \pm 0.488 \pm 0.40_{910} \\
0 \pm 0.47\end{array}\right.$ & $\begin{array}{c}=0.417 .688 \pm 0.403 \\
1.688 \pm 0.403\end{array}$ & $1.688 \pm 0.403$ \\
\hline Present study & 55 & $2.6903 \pm 0.52$ & $2.17 \pm 0.35$ & $1.91 \pm 33$ & & \\
\hline
\end{tabular}

The lung function reported from India and other parts of south Asia exhibit considerable diversity. Contributory factors are racial differences, use of a wide variety of equipments and numerous environmental influences including nutrition, climate, terrain and prevalence of diseases ${ }^{(24)}$. In India, several studies were carried out on school children to predict the lung function using anthropometric variables. The studies conducted on children at Chandigarh, ${ }^{[2]}$ Bombay, ${ }^{[3]}$ Delhi ${ }^{[4]}$ and Hyderabad 36 have projected different types of regression equations for lung functions in Indian children. Some of them had used age, height and weight, ${ }^{[4]}$ age and height, ${ }^{[5]}$ age and body surface $\operatorname{area}^{[2]}$ or height alone ${ }^{[25]}$ as independent variables for prediction of lung functions.

Vijayan et $a l,{ }^{[22]}$ in a study on south Indian children, showed that correlations of FVC and
$\mathrm{FEV}_{1}$ were highest with height followed by weight and age. Height influences the prediction equations in males to a greater extent whereas age and weight had greater influences in girls. Wang et al, ${ }^{[23]}$ concluded that for the same height boys, have greater lung function values than girls. $\mathrm{FEV}_{1} \%$ has shown negative correlation with height and age while statistically significant positive correlations with surface area, similar to Shamssain study. ${ }^{(7)}$

\section{Conclusion}

Variables such as FVC, FEV 1 show good positive correlation with height, age and body mass index in both sexes. There is a need to have regional values for the prediction of normal spirometric parameters in a country like India with considerable diversity. 


\section{References}

1. Vijayasekaran D, Subramanyam L, Balachandran A, Shivbalan S. Spirometry in clinical practice. Indian Pediatr. 2003; 40:626-32.

2. Mallik SK, Jindal SK. Pulmonary function tests in healthy children. Indian Pediatr. 1985;22:677-81.[PubMed]

3. Chowgule RV, Shetye VM, Parmar JR. Lung function tests in normal Indian children. Indian $\quad$ Pediatr. 1995;32:18591. [PubMed]

4. Sharma PP, Gupta P, Deshpande R, Gupta $P$. Lung function values in healthy children (10-15 years) Indian J Pediatr. 1997; 64:85-91. [PubMed]

5. Nair RH, Kesavachandran C, Sanil R, Sreekumar R, Shashidhar S. Prediction equation for lung functions in south Indian children. Indian J Physiol Pharmacol. 1997;41:390-6. [PubMed]

6. Connett GJ, Quak SH, Wong ML, Teo J, Lee BW. Lung function reference values in Singaporean children aged 6-18 years. Thorax. 1994;49:901-5. [PMC free article] [PubMed]

7. Shamssain MH. Forced expiratory indices in normal black southern African children aged 6-19 years. Thorax. 1991;46:175-9. [PMC free article] [PubMed]

8. Vohra RS, Shah SC, Shah GS. Pulmonary functions in normal children. Indian Paediatr 1984; 21: 785-790.

9. Chowgule RV, Shetye VM, Parmar JR. Lung function tests in normal Indian children. Indian Paediatr 1995; 32:185191.

10. Pande JN, Mohan A, Khilnani S, Khilnani GC. Normal values of peak expiratory flow rate in school going children. Indian ] Chest Dis Allied Sci 1997; 39 :87-95.

11. Quanjer PH, Stocks J, Polgar G, Wise M, Kalberg J, Borsboon G. Compilation of reference values for lung function measurements in children. Eur Respir $J$ 1989; 2 (suppl 4): 184-261.

12. Rosenthal M, Bain SH, Cramer D, et al. Lung function in white children aged 4 to 19 years: 1- spirometry. Thorax 1993; 48 : 794-802.

13. Rosenthal M, Cramer D, Bain SH, Denison D, Bush A, Warner JO. Lung function in white children aged 4 to 19 years: 2-single breath analysis and plethysmography. Thorax 1993; 48 :803808.

14. Mitchell EA. International trends in hospital admission rates for asthma. Arch Dis Child 1985; 60 :376-378.

15. Donnelly PM, Yang TS, Peat JK, Woolcock AJ. What factors explain racial differences in lung volumes? Eur Respir J1981; 4 : 829-38.

16. Vijayan VK, Kuppurao KV, Venkatesan P, Sankaran K, Prabhakar R. Pulmonary function in healthy young adult Indians in Madras. Thorax 1990; 45 : 611-15.

17. Miller MR, Hankinson J, Brusasco V, Burgos F, Casaburi R, Coates A, et al. Standardisation of spirometry. Eur Respir J. 2005;26:319-38.

18. Burrows B, Lebowitz MD, Camilli AE, Knudson RJ. Longitudinal changes in forced expiratory volume in one second in adults. Methodologic considerations and findings in healthy nonsmokers. Am Rev Respir Dis1986;133:974-980.

19. Raju PS, Prasad KV, Ramana YV, Ahmed SK, Murthy KJ. Study on lung function tests and prediction equations in Indian male children. Indian Pediatr. 2003; 40:705-11. [PubMed]

20. Deshpande JN, Dahat HB, Shirole CD, Pande AH. Pulmonary functions and their correlation with anthropometric parameters in rural children. Indian $\mathbf{J}$ Pediatr. 1983;50:375-8. [PubMed]

21. Shamssain MH, Thompson J, Ogston SA. Forced expiratory indices in normal 
Libyan children aged 6-19 years. Thorax. 1988;43:467-70. [PMC free article] [PubMed]

22. Vijayan VK, Reetha AM, Kuppurao KV, Venkatesan P, Thilakavathy S. Pulmonary function in normal south Indian children aged 7 to 19 years. Indian J Chest Dis Allied Sci. 2000;42:147-56.

23. Wang X, Dockery DW, Wypij D, Fay ME, Ferris BG., Jr Pulmonary function between 6 and 18 years of age. Pediatr Pulmonol. 1993;15:75-88

24. Sherrill DL, Lebowitz MD, Knudson RJ, Burrows B. Methodology for generating continuous prediction equations for pulmonary function measures. Comput Biomed Res 1991;24:249-260.

25. Raju PS, Prasad KV, Ramana YV, Ahmed SK, Murthy KJ. Study on lung function tests and prediction equations in Indian male children. Indian Pediatr. 2003; 40:705-11

26. Tahera H. Doctor, Sangeeta S. Trivedi and Rajesh K. Chudasama Pulmonary function test in healthy school children of 8 to 14 years age in south Gujarat region, India Lung India. 2010 Jul-Sep; 27(3): 145-148. 